\title{
Study on Growth and Survival of Giant Freshwater Prawn, Macrobrachium rosenbergii, in Tarai Agroclimatic Regime of Uttarakhand
}

\author{
Shashank Singh and R. S. Chauhan* \\ Department of Aquaculture, College of Fisheries \\ G. B. Pant University of Agriculture and Technology, Pantnagar (Uttarakhand), India - 263145
}

\begin{abstract}
Giant freshwater prawn, Macrobrachium rosenbergii, is a high value cultured aquatic species, commonly called as 'scampi' in trade circles. An experiment was conducted at Instructional Fish Farm of the College of Fisheries, Govind Ballabh Pant University of Agriculture and Technology, Pantnagar in four rectangular earthen ponds each of the size of 0.033 ha in tarai agroclimatic regime of Uttarakhand. The stocking of PL 10 was done @ 60000/ha. The pre-stocking management of the ponds included dewatering, drying, liming, organic manuring and watering of ponds. The water quality parameters were monitored regularly. The larvae were fed with starter feed upto 60 days of rearing when the larvae attained average weight of around $4 \mathrm{~g}$. Thereafter, juveniles were fed with grower feed @ 5\% body weight twice a day in two equal splitted doses. The sampling of the prawn was done at fortnightly intervals. The average weight of the prawn at the time of stocking was $0.04 \mathrm{~g}$ while after 180 days of culture at the time of harvesting the prawn attained average weight of $25.37 \pm 14.21 \mathrm{~g}$ with $76.95 \%$ survival. The average absolute growth rate of $0.140 \mathrm{~g} /$ day and specific growth rate of $1.55 \%$ was achieved during the experimental period. The calculated gross production of $1183.159 \mathrm{~kg}$ prawn/ha/crop of 180 days was obtained. The result of the study inferred that the culture of giant freshwater prawn, $M$. rosenbergii, is feasible in tarai agroclimatic regime of Uttarakhand. The fish farmers of the area can earn their sustainable livelihood through scampi farming.
\end{abstract}

Keywords: Macrobrachium rosenbergii, Growth, Survival, Production.

\section{Introduction}

Freshwater prawn is a highly priced commodity among the freshwater aquaculture species and share a large amount of total aquaculture production. About 200 species of Macrobrachium are found all over the world, of which 30 species abound Indian waters. The most important culturable species of genus Macrobrachium is rosenbergii. This prawn is commonly called as scampi in trade circles. In nursery ponds, stocking density varies from 200 to $400 / \mathrm{m}^{2}$. However, farmers generally adopt a moderate stocking density of 50 to $100 / \mathrm{m}^{2}$ without any aeration and water circulation. After 30-40 days of culture in nursery ponds the juveniles are transferred to grow-out ponds with varying stocking density of $5-10 / \mathrm{m}^{2}$. Most farmers, stock at a moderate stocking density of $6 / \mathrm{m}^{2}$ under semi-intensive type of monoculture system. Artemia is most preferred food of prawn larvae. Formulated pelleted feeds are usually given in grow-out culture twice daily at the rate of $3-5 \%$ of the biomass in feeding trays. Recently, farming of $M$. rosenbergii had been concentrated in maritime states due to ready availability of stocking material i.e. post larvae. But, it has also got entry into inland areas where brackish or saline soil or water is available. Tarai region is a unique agro-climatic zone where underground water level is very high and climate is hot and humid. There is no record of giant freshwater prawn farming in this region. In India, culture of giant freshwater prawn at stocking densities of 30000-50000/ 
ha has shown production levels of $1.0-1.5 \mathrm{t} / \mathrm{ha}$ in a culture period of 6-8 months (Ayyappan, 2007). In the first feasibility study of rearing $M$. rosenbergii in South African inland ponds in 1981 , promising yield of $1.2 \mathrm{t} / \mathrm{ha}$ was obtained in 172 days, with survival at $76 \%$ and a mean weight of nearly $29 \mathrm{~g}$ (Taylor et al., 1992). Culture of the giant freshwater prawn, Macrobrachium rosenbergii, has drawn the attention of aqua-culturists and fish farmers in many parts of the world because of its fast growth, adaptability to the poly-culture environment and artificial feed, greater disease resistance than its marine counterparts and high market demand. The popularity of this species has resulted in receiving the increasing attention of researchers in search for innovative culture technology (New, 2002). Various types of shelters/hideouts like PVC pipes, earthen pipes, aquatic weeds and used tyres have been used in prawn culture ponds. The present investigation is aimed to assess culture feasibility of Macrobrachium rosenbergii in tarai region of Uttarakhand, including study on survival and growth performance of scampi under semi-intensive monoculture in earthen ponds.

\section{Materials and Methods}

The experiment was carried out for a period of 180 days from $28^{\text {th }}$ May to $25^{\text {th }}$ November, 2011 at the Instructional Fish Farm of the College of Fisheries, G.B. Pant University of Agriculture and Technology, Pantnagar. The climatic condition of Pantnagar is humid, sub tropical and is characterized by hot dry summer and extremely cold conditions. The study was carried out in the four outdoor earthen rectangular ponds $\left(\mathrm{P}_{1}, \mathrm{P}_{2}, \mathrm{P}_{3}\right.$ and $\left.\mathrm{P}_{4}\right)$ of size $23 \mathrm{~m} \times 14.35 \mathrm{~m} \times 1.2 \mathrm{~m}$. Supply of water was ensured through a tube well oxygenated water to maintain average water depth of $0.80 \pm 0.10$ $\mathrm{m}$ throughout the experimental period. The ponds were dewatered, dried and liming was done @ 500kg/ha followed by initial manuring @ 2500kg raw cattle dung /ha. The used tyres and broken PVC pipes were used as hide-outs as shelter for prawns. Healthy stock of $M$. rosenbergii was procured from CIFE-sub centre, Rohtak, Haryana. The PL 10 was packed in oxygen filled polythene bags having 1000 larvae. The sealed polythene bags were kept in carton boxes. Transportation was done through road. The seed was properly acclimatized and stocked at the rate of 60000/ ha (2000/experimental pond of $\left.330 \mathrm{~m}^{2}\right)$. Supplementary feeding was done with starter feed (30\% protein) and grower feed (26\% protein) @ $5 \%$ body weight of the prawn twice a day in the two equal splitted doses during late morning and late afternoon. Prawns were sampled fortnightly for growth and health monitoring. The analysis of pond sediment viz. soil $\mathrm{pH}$, soil organic carbon, total nitrogen, available phosphorus, available potassium and soil texture was done. The water quality parameters viz. water- temperature, $\mathrm{pH}$, dissolved oxygen, free $\mathrm{CO}_{2}$ and total alkalinity in ponds were monitored regularly. The quantitative and qualitative analysis of plankton was also done. The average weight of prawn was measured at fortnightly intervals by using hide-outs or by netting out prawn in equal numbers from each pond and weight of each prawn was measured separately. Absolute growth rate (g/day) was evaluated by using the following formula given by Wood et al. (1983).

$$
\text { Abosolute growth rate }=\frac{\left(w_{1}-w_{0}\right)}{T}
$$

Where, $W_{1}=$ Prawn weight at the end of study, $g ; W_{0}=$ Prawn weight at start of study, $g$ and $\mathrm{T}=$ Time interval in days

On the basis of collecting average weight data, specific growth rate (SGR) was calculated by using following formula-

$S G R=\frac{\ln \log (\text { final weight })-\ln \log (\text { initial weight })}{\text { Time }(\text { days })} \times 100$

Survival rate of the prawn was also calculated by using following formula

$$
\text { Survival rate }(\%)=\frac{\text { Nos. recovered }}{\text { Nos. stocked }} \times 100
$$


The gross production of $M$. rosenbergii from experimental ponds was estimated at the end of study in terms of $\mathrm{kg} / \mathrm{ha} / \mathrm{crop}$ of 180 days. Data collected from the experiment were subjected to one way analysis of variance (ANOVA) test using the statistical package (STPR 43).

\section{Results and Discussion}

Analysis of variance showed that the difference in water quality among experimental ponds was non-significant and within acceptable limits for culture of giant freshwater prawn. The plankton population consisted of Chlorophyceae, Bacillariophyceae, Cyanophyceae and Euglinophyceae from phytoplankton whereas Rotifers, Copepods and Cladocerans from zooplankton. The details of minimum, maximum and average weight of prawns at 15 days interval are included in Table 1.The similar result was obtained by Davassi (2011) at the end of 6 months culture where he found final average weight of $28.06 \mathrm{~g}, 32.02 \mathrm{~g}, 35.50 \mathrm{~g}, 25.05 \mathrm{~g}$ and $22.00 \mathrm{~g}$ when the initial weight of the prawn was $1.00 \mathrm{~g}, 1.03 \mathrm{~g}, 0.90 \mathrm{~g}, 0.94 \mathrm{~g}$ and $0.97 \mathrm{~g}$ respectively on different diets. In the culture period of
180 days, Sarkar et al. (1998) recorded final weight of $68 \pm 4.9 \mathrm{~g}, 65 \pm 4.0 \mathrm{~g}$ and $78 \pm 3.9 \mathrm{~g}$ respectively in feed, cow dung and cow dung + feed management regimes in earthen ponds,. The details of absolute growth rate of giant freshwater prawn evaluated at every 15 days intervals are presented in Table 2 . The value of specific growth rate is used to compare growth on daily basis. The SGR was estimated at 15 days intervals and presented in Table 3. Gupta et al., (2011) observed the specific growth rate of scampi as $1.84 \pm 0.46$ to $2.24 \pm 0.56$ on different diet composition. Felix and Jayaseelan (2006) found the highest SGR of post larvae of $M$. rosenbergii on $40 \%$ protein feed $(6.635 \pm$ $0.095)$ and lowest on $25 \%$ protein feed $(5.148 \pm$ 0.072 ) when they fed the scampi with feeds containing different protein levels (15-45\% protein feed). Davassi (2011) estimated SGR ranging from 1.73 to 2.04 on different diets.

In the present study the maximum survival was observed in pond $\mathrm{P}_{1}$ (Table 4). Average survival was observed as $76.95 \%$. Davassi (2011) found very low survival rate i.e. $13.33-40.00 \%$ on different diets. In the study on Macrobrachium

Table 1 Details of sampling of freshwater prawn from different experimental ponds (average weight in $\mathrm{g} \pm \mathrm{SD}$ ).

\begin{tabular}{|c|c|c|c|c|c|c|c|c|c|c|c|c|c|}
\hline \multirow{3}{*}{ Days } & \multicolumn{12}{|c|}{ Ponds } & \multirow{3}{*}{$\begin{array}{c}\text { Pooled } \\
\text { Avg. } \\
\end{array}$} \\
\hline & \multicolumn{3}{|c|}{$\mathbf{P}_{1}$} & \multicolumn{3}{|c|}{$\mathbf{P}_{2}$} & \multicolumn{3}{|c|}{$P_{3}$} & \multicolumn{3}{|c|}{$P_{4}$} & \\
\hline & Min. & Max. & Avg. & Min. & Max. & Avg. & Min. & Max. & Avg. & Min. & Max. & Avg. & \\
\hline 0 & - & - & $0.04 \pm 0.00$ & - & - & $0.04 \pm 0.00$ & - & - & $0.04 \pm 0.00$ & - & - & $0.04 \pm 0.00$ & $0.04 \pm 0.00$ \\
\hline 15 & 0.22 & 0.48 & $0.31 \pm 0.08$ & 0.22 & 0.48 & $0.33 \pm 0.08$ & 0.21 & 0.48 & $0.35 \pm 0.08$ & 0.21 & 0.50 & $0.36 \pm 0.09$ & $0.34 \pm 0.08$ \\
\hline 30 & 0.24 & 0.87 & $0.62 \pm 0.16$ & 0.42 & 0.92 & $0.68 \pm 0.13$ & 0.42 & 0.98 & $0.75 \pm 0.13$ & 0.29 & 1.17 & $0.75 \pm 0.25$ & $0.70 \pm 0.18$ \\
\hline 45 & 0.42 & 1.87 & $0.97 \pm 0.41$ & 0.62 & 1.63 & $1.08 \pm 0.29$ & 0.33 & 1.89 & $1.13 \pm 0.46$ & 0.51 & 2.11 & $1.15 \pm 0.44$ & $1.08 \pm 0.41$ \\
\hline 60 & 1.28 & 3.28 & $2.47 \pm 0.52$ & 1.49 & 4.12 & $2.54 \pm 0.58$ & 1.20 & 4.19 & $2.66 \pm 0.89$ & 0.53 & 6.83 & $2.98 \pm 1.59$ & $2.66 \pm 1.00$ \\
\hline 75 & 2.02 & 5.39 & $4.18 \pm 0.98$ & 2.08 & 7.23 & $4.28 \pm 1.41$ & 2.18 & 7.14 & $4.32 \pm 1.41$ & 2.24 & 10.99 & $4.54 \pm 1.90$ & $4.33 \pm 1.45$ \\
\hline 90 & 1.83 & 22.3 & $7.68 \pm 4.69$ & 3.94 & 13.13 & $7.80 \pm 2.43$ & 4.09 & 11.76 & $7.83 \pm 2.15$ & 4.56 & 11.31 & $7.89 \pm 2.00$ & $7.80 \pm 2.98$ \\
\hline 105 & 4.82 & 33.7 & $10.05 \pm 6.39$ & 6.62 & 23.21 & $12.88 \pm 3.89$ & 8.62 & 18.53 & $13.15 \pm 3.30$ & 8.20 & 18.67 & $13.69 \pm 3.00$ & $12.44 \pm 4.52$ \\
\hline 120 & 9.43 & 29.94 & $12.33 \pm 4.36$ & 7.98 & 36.60 & $15.73 \pm 7.27$ & 2.83 & 32.64 & $17.16 \pm 7.69$ & 6.40 & 41.12 & $17.92 \pm 9.45$ & $15.79 \pm 7.64$ \\
\hline 135 & 10.00 & 43.15 & $13.58 \pm 6.13$ & 11.49 & 40.40 & $18.54 \pm 7.74$ & 5.02 & 59.75 & $19.20 \pm 12.51$ & 12.58 & 39.85 & $21.79 \pm 7.62$ & $18.28 \pm 9.22$ \\
\hline 150 & 11.02 & 46.79 & $14.89 \pm 6.57$ & 10.82 & 51.90 & $21.76 \pm 9.81$ & 11.12 & 49.93 & $22.45 \pm 10.04$ & 14.35 & 58.59 & $25.12 \pm 10.28$ & $21.06 \pm 9.93$ \\
\hline 165 & 11.18 & 45.32 & $16.42 \pm 6.12$ & 10.76 & 57.00 & $22.89 \pm 10.14$ & 16.30 & 48.81 & $25.81 \pm 8.92$ & 16.55 & 79.66 & $28.16 \pm 14.11$ & $23.32 \pm 11.03$ \\
\hline 180 & 6.38 & 72.17 & $19.54 \pm 9.49$ & 0.31 & 66.48 & $24.00 \pm 11.91$ & 2.06 & 83.78 & $28.11 \pm 17.08$ & 4.6 & 98.49 & $30.48 \pm 15.01$ & $25.37 \pm 14.21$ \\
\hline
\end{tabular}


Table 2 Absolute growth rate (g/day) of Macrobrachium rosenbergii in different Experimental ponds.

\begin{tabular}{|l|c|c|c|c|c|}
\hline \multirow{2}{*}{ Days } & \multicolumn{4}{|c|}{ Ponds } & \multirow{2}{*}{ Pooled } \\
\cline { 2 - 5 } & $\mathbf{P}_{1}$ & $\mathbf{P}_{\mathbf{2}}$ & $\mathbf{P}_{3}$ & $\mathbf{P}_{4}$ & \\
\hline $\mathbf{1 5}$ days & 0.0180 & 0.0193 & 0.0206 & 0.0213 & 0.0200 \\
\hline $\mathbf{3 0}$ days & 0.0206 & 0.0233 & 0.0266 & 0.0266 & 0.0240 \\
\hline $\mathbf{4 5}$ days & 0.0233 & 0.0266 & 0.0253 & 0.0266 & 0.0253 \\
\hline $\mathbf{6 0}$ days & 0.1000 & 0.0973 & 0.1020 & 0.1220 & 0.1053 \\
\hline $\mathbf{7 5}$ days & 0.1140 & 0.1160 & 0.1106 & 0.1040 & 0.1113 \\
\hline $\mathbf{9 0}$ days & 0.2333 & 0.2346 & 0.2340 & 0.2233 & 0.2313 \\
\hline $\mathbf{1 0 5}$ days & 0.1580 & 0.3386 & 0.3546 & 0.3866 & 0.3093 \\
\hline $\mathbf{1 2 0}$ days & 0.1520 & 0.1900 & 0.2673 & 0.2820 & 0.2233 \\
\hline $\mathbf{1 3 5}$ days & 0.0833 & 0.1873 & 0.1360 & 0.2580 & 0.1660 \\
\hline $\mathbf{1 5 0}$ days & 0.0873 & 0.2146 & 0.2166 & 0.2220 & 0.1853 \\
\hline $\mathbf{1 6 5}$ days & 0.1020 & 0.0753 & 0.2240 & 0.2026 & 0.1506 \\
\hline $\mathbf{1 8 0}$ days & 0.2080 & 0.0740 & 0.1533 & 0.1546 & 0.1366 \\
\hline
\end{tabular}

Table 3 Specific growth rate (\% bw/d) of Macrobrachium rosenbergii in different Experimental ponds.

\begin{tabular}{|l|c|c|c|c|c|}
\hline \multirow{2}{*}{ Days } & \multicolumn{4}{|c|}{ Ponds } & \multirow{2}{*}{ Pooled } \\
\cline { 2 - 5 } & $\mathbf{P}_{1}$ & $\mathbf{P}_{\mathbf{2}}$ & $\mathbf{P}_{3}$ & $\mathbf{P}_{\mathbf{4}}$ & \\
\hline $\mathbf{1 5}$ days & 5.93 & 6.11 & 6.28 & 6.36 & 6.20 \\
\hline $\mathbf{3 0}$ days & 2.01 & 2.09 & 2.21 & 2.13 & 2.09 \\
\hline $\mathbf{4 5}$ days & 1.30 & 1.34 & 1.19 & 1.24 & 1.26 \\
\hline $\mathbf{6 0}$ days & 2.71 & 2.48 & 2.48 & 2.76 & 2.61 \\
\hline $\mathbf{7 5}$ days & 1.52 & 1.51 & 1.40 & 1.22 & 1.41 \\
\hline $\mathbf{9 0}$ days & 1.76 & 1.74 & 1.72 & 1.60 & 1.70 \\
\hline $\mathbf{1 0 5}$ days & 0.78 & 1.45 & 1.50 & 1.60 & 1.35 \\
\hline $\mathbf{1 2 0}$ days & 0.59 & 0.58 & 0.77 & 0.78 & 0.69 \\
\hline $\mathbf{1 3 5}$ days & 0.28 & 0.48 & 0.33 & 0.57 & 0.42 \\
\hline $\mathbf{1 5 0}$ days & 0.27 & 0.46 & 0.45 & 0.41 & 0.41 \\
\hline $\mathbf{1 6 5}$ days & 0.28 & 0.15 & 0.40 & 0.33 & 0.30 \\
\hline $\mathbf{1 8 0}$ days & 0.50 & 0.14 & 0.25 & 0.23 & 0.24 \\
\hline
\end{tabular}

malcolmsonii juveniles fed with different feeds for 60 days, Soundarapanadian et al. (2002) observed survival ranging from $92.1 \pm 0.6$ to $95.6 \pm 0.9 \%$. Gupta et al. (2011) found survival of scampi varying from $63.80 \pm 7.30$ to $77.70 \pm$ $10.20 \%$ that is more or less similar to the present experiment. Sarkar et al., (1998) found the survival of $80 \pm 2.7$ to $84 \pm 3.0 \%$ under three different management regimes.

With 6156 prawns recovered $(76.95 \%$ survival) each averaging weight of $25.37 \mathrm{~g}$, a gross production of $156.177 \mathrm{Kg}$ was obtained from combined area of $1320 \mathrm{~m}^{2}$ of four experimental ponds. This equals calculated gross production of $1183.159 \mathrm{~kg}$ prawn/ha/ crop of 6 months. Fatema et al. (2011) recorded production of giant freshwater prawn ranging from 529.32 to $715.19 \mathrm{Kg} / \mathrm{ha} / \mathrm{crop}$ of 120 days. Nagarathinam et al. (2000) obtained estimated production of $M$. rosenbergii in monoculture grow-out ponds as 984.34 and $1662.26 \mathrm{Kg} / \mathrm{ha} / \mathrm{crop}$ of 180 days for two different stocking densities.

It is inferred from the results that culture of freshwater prawn, $M$. rosenbergii, is feasible in tarai agroclimatic region of Uttarakhand. Thus, the fish farmers of the area may adopt culture practice of scampi to earn their sustainable livelihood. 


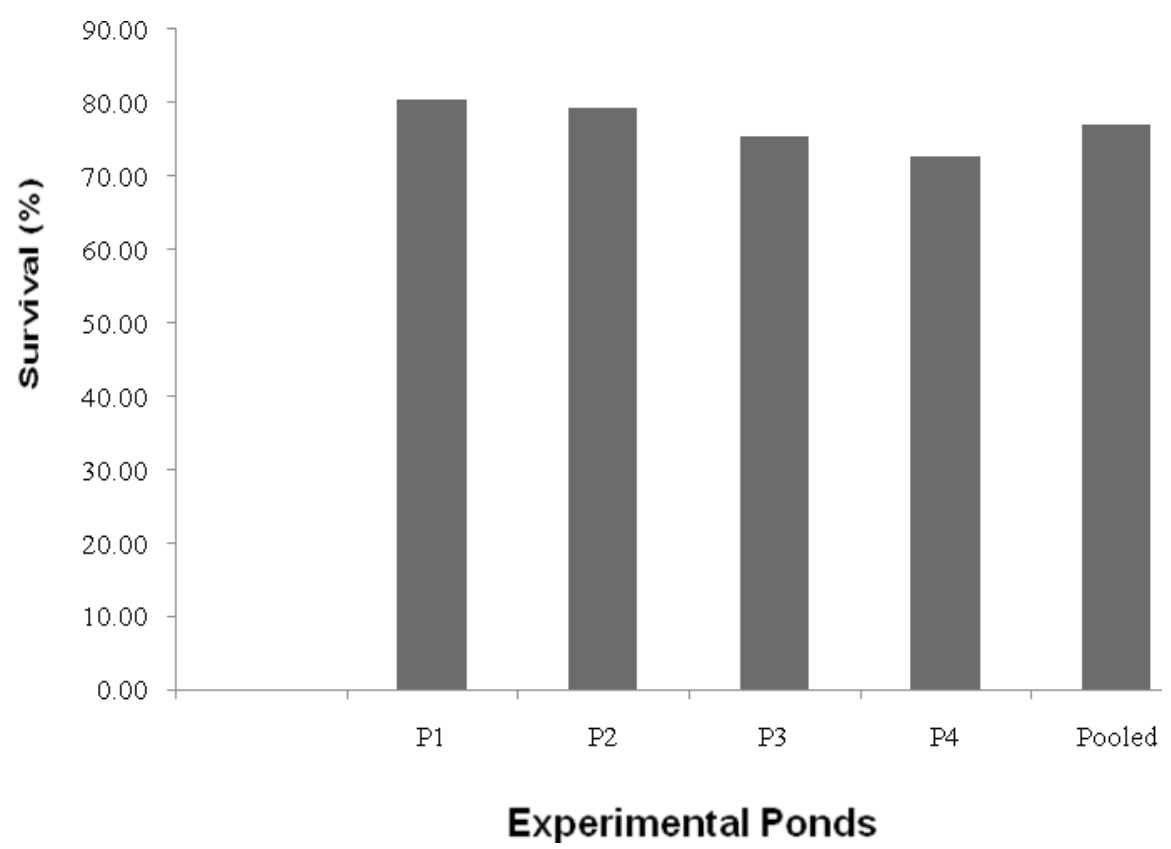

Fig.1 Survival rate of giant freshwater prawn in experimental ponds.

\section{Acknowledgement}

The authors are thankful to Dean, College of Fisheries, G. B. Pant University of Agriculture and Technology, Pantnagar for providing facilities to carry out present work.

\section{References}

APHA (1985) Standard Methods for the Examination of Water and Waste Water (16 $6^{\text {th }}$ edition). American Public Health Association, New York.

Ayyappan, S. (2007)Growth through inland aquaculture. In: Proc. $8^{\text {th }}$ Agricultural Science Congress of National Academy of Agricultural Science, Tamil Nadu Agricultural University, Coimbatore, India. pp 1-19.

Davassi, L.A. (2011) Survival and growth of the freshwater prawn Macrobrachium rosenbergii in relation to different nutrients composition. J. Fish. Aquatic Sci., 6, 649-654.

Fatema, K., Wahab, M. A., Pervin, R., Khan, M.S.R. and Roy, H.C. (2011) Comparison of growth and production performance between male and female giant freshwater prawn in combination with Mola. J. Environ. Sci. Natural Resour., 4, 137-142

Felix, N. and Jayaseelan, M. J .P. (2006) Effects of different protein diets on growth and food conversion ratio (FCR) of postlarvae of $M$. rosenbergii (De Man). Ind. J. Fish., 53, 175-180.
Gupta, A., Sehgal, H. S. and Sehgal, G. K. (2011) Low-cost diet for monoculture of giant Macrobrachium rosenbergii. Indi. J. Animal Nutr., 28, 54-63.

Nagarathinam, N., Kumar, J. S. S. and Sundararaj, V. (2000) Influence of stocking density on growth, production and survival of Macrobrachium rosenbergii (de Man) in a monoculture grow-out pond. Ind. J. Fish., 47, 103-108.

New, M.B. (2002) Farming Freshwater Prawns: A manual for the culture of the giant river prawn (Macrobrachium rosenbergii). FAO Fisheries Technical Paper No. 428, FAO, Rome.

Sarkar, S. K., Charaborty, M. and Das, R. N. (1998) Role of integrated use of cowdung and pelleted feed in production of Macrobrachium rosenbergii in freshwater ponds. Ind. J. Fish., 45, 61-66.

Soundrapandian, P., Ravichandran, S. and Kannupandi, T. (2002) Effect of live and artificial feeds on the growth and survival of Macrobrachium malcolmsonii $(\mathrm{H}$. Milne Edwards) larvae and juveniles. Ind. J. Fish.,49, 79-84.

Taylor, L. R., Schoonbee, H. J. and Ferreira J. T. (1992) Observations on the production of the giant freshwater prawn, Macrobrachium rosenbergii, in the Transvaal, South Africa. Water South Africa., $18,1-6$.

Wood, L. C., Korby, J. H. and Huish, M. T. (1983) Estuarine cage culture ofhybrid stripped bass. $J$. World Mariculture., 14, 200-612. 
